\title{
THE PLACE OF NATURE STUDY IN THE ELEMENTARY SCHOOL CURRICULUM.
}

By S. H. WILliams,

State Normal School, Slippery Rock, Pa.

The development of esthetic appreciation in any individual is closely associated with the elevation of mind to a higher plane of moral ethics.

In no other way can this appreciation be greater imbured than by introducing to the individual the wonders of the natural world. This introduction should be made early in his life, just as is the training in morality, ethics, and social responsibilities, and proceed through successive stages of intensive observation to and through adolescence when, by virtue of previous training, he will continue his observations and investigations with a manifest interest which will lead him into realms of Nature's glory and closely associate him with that divine power which has made all things possible.

We have made one advance in this direction by shifting the study of natural science from the college to the secondary schools where Chemistry, Physics, and Biology are taught sometimes in, I am afraid, a rather indifferent way. We have further broadened our vision and established a course in General Science in the first year of the secondary schools. Of course the Science has not yet reached its plane of perfection or greatest usefulness but its progress indicates that it will shortly attain an effectiveness that will emphasize its importance.

It is true that the place Natural Science now holds in the curriculum of the various grades of schools, has been made possible after a long and bitter struggle against the inertia of prejudice and routine but the victory has been a glorious one.

But why stop here? To postpone the revelations of Science until the adolescent period is analogous to beginning the study of the history of civilization at the sixteenth century without reference to the preceding ages through which it has evolved and from which the greater part is inherited. Or like beginning Algebra at Quadratics. Furthermore when a child reaches the age of puberty he has passed the age of "inquisitiveness," during which he has made our lives miserable with his incessant propounding of questions relative to the moon, stars, the rainbow, clouds, colors and odors of flowers, the birds, and a multitude of other things which only the imaginative, wondering, unconcentrated mind of a child could think of -of t times to our shame 
and embarrassment at being unable to explain them. As a consequence, we ourselves can remember how our desires to know these things were suppressed by a "run along and play I'm busy and don't (emphasis on the don't) ask so many questions." This remark was often accompanied by the quotation of the old saying, "A fool can ask more questions than a dozen wise men can answer." But these questions are not foolish and we should see to it that the parents and teachers of the future will be able to answer them and enlighten the questioner as well as to encourage him in his desire to know.

Isn't it logical that this period is the time of times to make the introduction of the charms and wiles of Mother Nature to the youth?

Then why wait until the boy and girl have reached the High School, where they are confronted with the cold indifferent facts of Chemistry and Physics, before making their debut in the field of Science? Why waste the golden opportunities in child life when their very souls are burning to know-to learn-to love?

There is a saying that "It is hard to teach an old dog new tricks," and as certain as are the immortal truths of Geometry is it that after the child has reached adolescence it is harder to interest him in a new field. This is partly because he has become indifferent to the things which have been a part of his environment all his life and he has learned to take them as a matter of course. This would be a sad and sorrowful world if the training in morals and religion were postponed until this time. But if the secrets are revealed during his early life-how they grow, how the desire to know and learn more will manifest itself in productive effort.

Therefore it is advisable that a course in nature study be incorporated in the elementary school curriculum. Connect the collegiate and secondary courses with a primary foundation and they will be productive of more good.

The traditional method of introducing the Sciences in to the schools first from the university to the college and from the college to the secondary schools has been like starting to build a chimney from the top downward and unlike any other subject that has ever received a place in the course of study. We do not begin mathematics at Calculus but proceed from the most elementary foundation. Neither do we begin Latin by reading Horace. So we must have a gradation of subjects in Science. 
We must lay a foundation on which to build and proceed carefully to construct a stable, thorough knowledge which will precede a higher step on the ladder of learning.

It is easy to assert that the course should be given but when the matter of what it should contain is considered it causes no little concern for each teacher of Science has a different idea of the content. There are so many wonderful things in nature that it is difficult to choose those things which are of most worth. But one thing at least will be agreed upon; the course should contain elementary explanations of things which are constantly before the student, the common things, if you please, the knowledge of which will aid him in his struggle for existence and develop in him that esthetic appreciation, which is so valuable an asset to any individual and to the group.

In the elementary grades stories of animals, plants, and natural phenomena, told in the same way and in the same language as the "Uncle Remus" tales, or in the form of the beautiful story of the "Two Rain Drops" which was written by Doctor F. B. Pearson, former Superintendent of Public Instruction, in Ohio, could be used to advantage. These stories could replace, to a certain extent, the mythical tales about Santa Claus, etc.,"which lead the child to believe in something with so strong a conviction that when he learns that his idol is imaginary and false it causes utmost grief. I know of many a child who has cried as though his little heart would break when informed that there was no such a being as Santa Claus.

There may be some who will ask how much of this will be remembered by the child after years have gone by when he will be called upon to utilize this knowledge. I would answer such a person in a truly American fashion of answering a question by asking one. How much does he remember of anything he has studied? Furthermore how many of us have studied Mother Goose since the days of our childhood yet in the entertainment of our children we can sing and recite those little songs and stories by the hour. There will be some who can and will make rhymes of some of this information, although that would not be my idea for I believe we agree with Oppenheim that rhymes are the hardest things for a child to learn and understand. We do not want the facts to be learned in a sing-song manner but rather told and learned in a way which the word learn implies. Nor do I wish to eliminate the little fairy tales which mean so much to the child in the period of "make believe," for I love 
children too much to rob them of any of their joys. But the truth, if properly told, is more fascinating than fiction and will do infinitely more good.

In the intermediate grades school gardens, home experiments, and school projects may be utilized. In the Grammar Grades laboratory and field work may be ably done and insect collections made. That this motivates the work in the whole school is subscribed to by many schools in the United States where this is in part carried out.

I shall not present here my outline of the course for the various grades, as it is not my intention to thrust upon others my ideas as to content but rather to present an argument for the course which should be standardized by the blending of ideas of a large number of capable teachers and students. There will be a tendency, no doubt, as was the case in General Science, to emphasize the divisions of Seience in which the writer of text books is especially versed or interested. But no course of study has ever stood the test of time but has been subjected to the tests of usefulness and efficiency. So, too, the work in Nature study will be tested and varied until its plane of greatest good has been determined. It will be the object of criticism and ridicule, but like the others it will soon, perhaps sooner than we think, find its channel and when this has been accomplished; when it begins to function properly, this old world of ours will be a better place in which to live.

\section{THE OUTLINE OF A COURSE IN PRACTICAL CHEMISTRY FOR GIRLS.}

By Charles E. Dull,

South Side High School, Newark, N. J.

Feeling that the college preparatory course in chemistry does not meet the needs of students who enter business directly from high school and that it is not well suited to girls who enter normal school, we are giving courses in chemistry which we believe such students will find of more value to them than the regular preparatory work.

In the chemistry for girls, the nature of chemical action, how chemical changes are brought about, and the demonstration of the various classes of chemical change are taught in practically the same manner as in the regular preparatory chemistry.

In the study of oxygen and hydrogen, their preparation is left entirely to the laboratory. In discussing their properties, 